\title{
Oxidized tissue proteins after intestinal reperfusion injury in rats ${ }^{1}$
}

\author{
Proteínas teciduais oxidadas após lesão intestinal por reperfusão em ratos
}

\author{
Alberto Schanaider², Vinícius José Martinho Toledo Menezes ${ }^{3}$, Aline Cury Borchardt ${ }^{3}$, Pedro Lagerblad de Oliveira ${ }^{4}$, \\ Kalil Madi ${ }^{5}$ \\ 1. Research from the Department of Surgery, Faculty of Medicine (FM), Federal University of Rio de Janeiro (UFRJ). \\ 2. Associate Professor of the Department of Surgery, FM/UFRJ. \\ 3. Medicine graduate student, FM/UFRJ, scientific initiation scholarship of FAPERJ. \\ 4. Associate Professor of the Department of Medical Biochemistry, Biomedical Science Institute, UFRJ. \\ 5. Professor of the Department of Pathology, FM/UFRJ.
}

\begin{abstract}
Purpose: To analyse if the carbonyl proteins measurement could be validated as a method that allows the identification of an intestinal oxidative stress after ischemia and reperfusion injury. Methods: Twenty-five male Wistar rats ( $\mathrm{n}=21)$ weighting 200 to 250 g were divided into three groups. Group I - control $(n=10)$. Group II - sham $(n=5)$ and Group III $(n=10)$ subjected to 60 minutes of intestinal ischemia and equal period of reperfusion. For this purpose it was clamped the superior mesenteric artery in its distal third. Histological changes and carbonyl protein levels were determined in the samples of all groups. In group III, samples of both normal and reperfused ileal segment were studied. Results: All the reperfused segments showed mucosal and submucosal swelling and inflammatory infiltrate of the lamina propria. Levels of carbonyl protein rose in group III, including in the non-ischemic segments. The sensitivity and specificity of the carbonyl protein tissue levels were respectively 94\% and 88\%. Conclusion: The carbonyl protein method is a useful biologic marker of oxidative stress after the phenomenon of intestinal ischemia and reperfusion in rats. It was also noteworthy that the effects of oxidative stress could be seen far from the locus of the primary injury.
\end{abstract}

Key words: Reperfusion. Oxidative stress. Rats.

\section{RESUMO}

Objetivo: Analisar se a mensuração da proteína carbonilada pode ser validada como método capaz de permitir a identificação de um estresse oxidativo intestinal causado por lesões decorrentes da isquemia e reperfusão. Métodos: Vinte e cinco ratos machos da linhagem Wistar, pesando entre 200 e 250g, foram divididos em três grupos. Grupo I - controle ( $\mathrm{n}=10)$. Grupo II - simulação $(n=5)$ e grupo III $(n=10)$ submetido a 60 minutos de isquemia intestinal e igual intervalo para reperfusão. Para este fim clampeou-se a artéria mesentérica superior no seu terço distal. Alterações histológicas e os níveis de proteínas carboniladas foram determinados em amostras obtidas em todos os grupos. No grupo III foram estudados segmentos ileais reperfundidos e normais. Resultados: Em todos os segmentos reperfundidos houve edema da mucosa e submucosa, além de infiltrado inflamatório da lâmina própria. Os níveis de proteína carbonilada aumentaram no grupo III, inclusive nos segmentos não isquemiados. A sensibilidade e a especificidade da proteína carbonilada no tecido foram, respectivamente, de $94 \%$ e $88 \%$. Conclusão: O procedimento da proteína carbonilada é útil como marcador biológico do estresse oxidativo após isquemia e reperfusão intestinal em ratos. Também foi relevante o efeito do estresse oxidativo, observado à distância do lócus da lesão primária.

Descritores: Reperfusão. Estresse oxidativo. Ratos

\section{Introduction}

Active species of oxygen have been increasingly implicated as mediators of the phenomenon of intestinal ischemia and reperfusion injury. ${ }^{1,2}$. It has been recognized that when the defence system is overwhelmed by an exceeding rate of oxygen radicals production, a chain reaction that causes structural damage occurs. In such circumstances not only the cellular membrane, but also the citoskeleton and the DNA are affected. ${ }^{2}$ The oxidative process introduces carbonyl groups into the proteins and this modification could be detected by using a specific method..$^{3-7}$ The first step of this research line is to prove the efficacy of carbonyl protein measurement as a biomarker of the intestinal reperfusion injury.

\section{Methods}

Twenty-five male Wistar rats (rattus norvegicus), weighing 200 to $250 \mathrm{~g}$, were randomly divided into three groups. To anaesthesia it was used intraperitoneal administration of Xilasine (3mg/kg) and Ketamine (25mg/ $\mathrm{kg}$ ). Group I served as control group. In group II it was only performed a two hours long laparotomy. In group III a 
microvascular clamp was placed on the distal third of the superior mesenteric artery for 60 minutes, followed by another 60 minute period of reperfusion. After that a distal segment of the ileum $(5 \mathrm{~cm})$ was excised and submitted to histological assessment and protein carbonyl evaluation. Tissue samples of distal ileum, were fixed with FAM solution (a mixture of formaldehyde $10 \%$, acetic acid $10 \%$ and methanol 80\%) embedded in paraffin, cut and stained with hematoxylin and eosin and examined by light microscopy. The carbonyl assay required 300 ì of homogenized intestine that was mixed with 33,3 ì of streptomycin followed by centrifugation at $5000 \mathrm{~g}$ for 10 minutes. After this step, it was added $840 \mathrm{iL}$ of $\mathrm{HCl}$ 2,5 M and $840 \mathrm{iL}$ of DNPH 20 mM. The tubes were vortexed for a period of one hour. Then, 840 ìL of TCA $20 \%$ was added, placed in an ice bath for $10 \mathrm{~min}$ and centrifuged for $10 \mathrm{~min}$ at $5000 \mathrm{~g}$. After centrifugation the pellets were washed out four times with $840 \mathrm{iL}$ of EtOH. The protein samples were resuspended in 840 ì of guanidine hydrochloride. This solution was centrifuged and incubated at $37^{\circ} \mathrm{C}$ in a water bath for 10 minutes. Finally, the carbonyl content was analysed using a spectrophotometer Hitachi U-100, and the values obtained were read from absorbance measurement at $366 \mathrm{~nm}$. Samples were run in duplicate. The results were assessed by the $\mathrm{T}$ test, considering $\mathrm{p}<0,05$ as significant values. Calculation of sensitivity and specificity were done according the following approach: Sensitivity = true positive/(true positive + falsenegative); specificity = true negative/(true negative and false positive). It was also used the Receiver Operator Characteristics (ROC) Curve

\section{Results}

All samples of group III showed considerable injury, but in the non-reperfused ileum, lesions were not so intense as those found in the ischemic segments. It was observed edema of mucosa and submucosa with massive inflammatory infiltration of the lamina propria, desquamation of epithelial cells of the upper third of the villi, decrease in the number of the goblet cells. The crypt length was greater than in normal intestines. (Figure 1). The levels of carbonyl proteins were significant in group III $(\mathrm{p}<0,05)$. There were no significant differences between groups I and II (Figure 2).

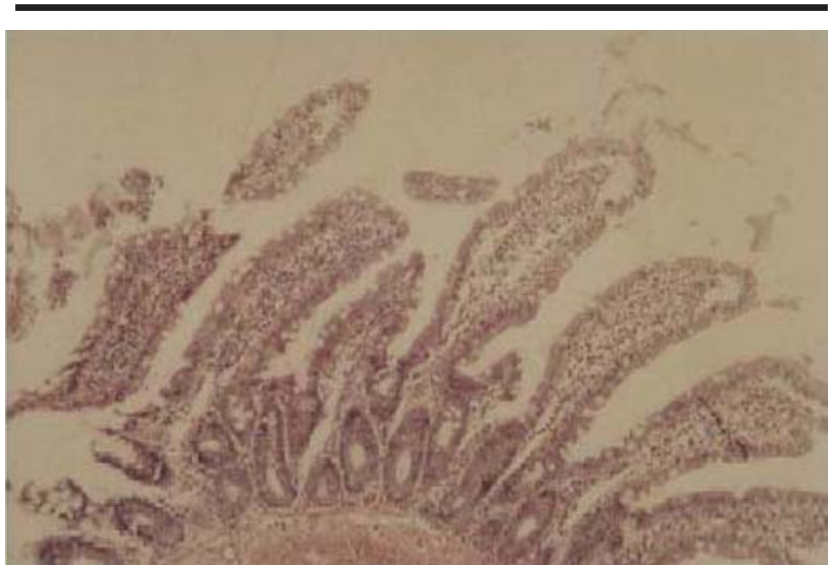

FIGURE 1 - Photomicrograph showing huge tissue injury after intestinal reperfusion (HE, X100).
The sensitivity and sensibility were high, respectively 94\% and 88\%, and the ROC curve confirmed the consistency of the biochemical method (Figure 3).

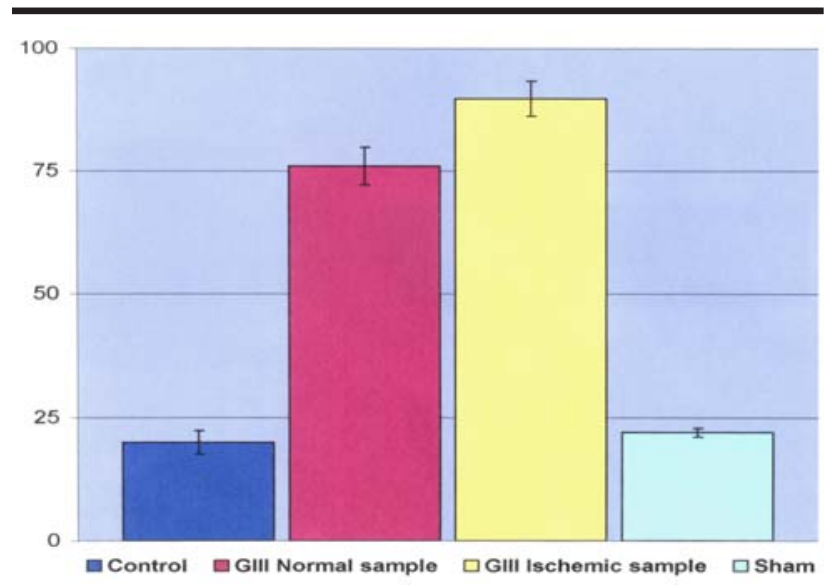

FIGURE 2 - Carbonyl protein/Total protein (mg/ml).

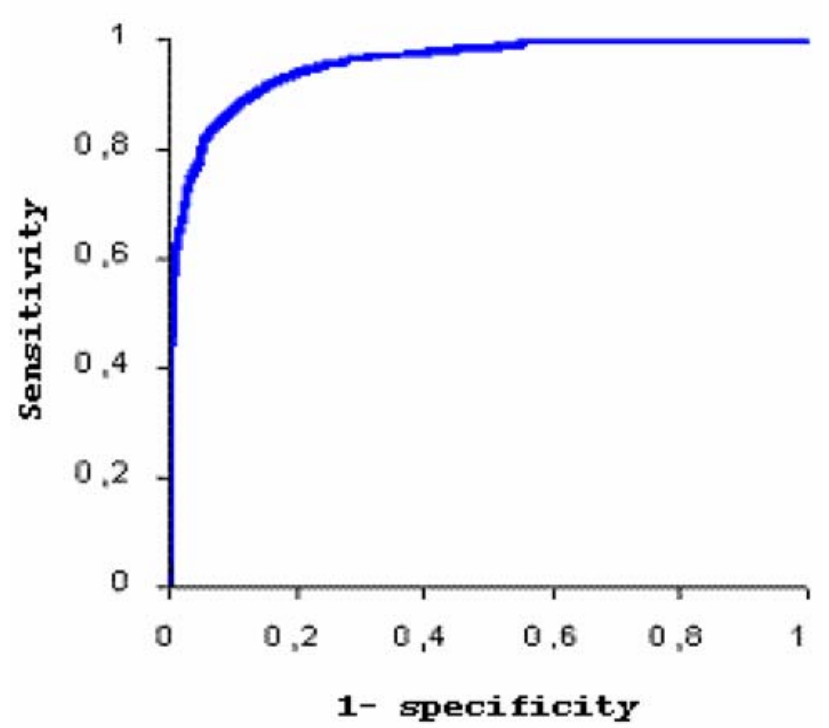

FIGURE 3 - ROC curve for carbonyl protein.

\section{Discussion}

Free oxygen radicals damage is involved in several pathologic conditions, including ischemia and reperfusion injuries, inflammatory diseases and aging process. ${ }^{4,8-16}$ Oxidative stress plays a central role in the cellular injury. Scavenge defence mechanisms could be insufficient to cope with reactive oxygen species (ROS) overproduced in a chain reaction. It results in amino acid side chains alteration, protein fragmentation, citoskeletolysis and cross-linking aggregation. ${ }^{11}$ Thus one of the main ultra structural change that characterizes the oxidative injury is the protein bound carbonyl group formation. Not only ROS and hypochlorous acid, a neutrophil-derived free radical, but also lipid peroxidation products or reducing sugars cause protein damage $^{11,17}$ Amino acid residues from lysine, proline or threonine are directly affected by oxidative reaction form the carbonyl derivatives. Some studies, both in vivo and in 
vitro, have provided growing evidence that carbonyl proteins could be a useful biological marker of the oxidative stress. ${ }^{13,15,17}$ Nevertheless the relationship among protein dysfunction and human diseases remain unclear. In the present study we face the challenge to identify oxidized proteins in intestinal reperfusion phenomenon. Our experimental model was established in previous studies ${ }^{2}$ and does not offer technical hitches. Histological results were compatible with reperfusion tissue injury and similar to others done in recent years. ${ }^{1,2}$ However the actual contribution of this study was to propose the measurement of carbonyl proteins after an intestinal reperfusion. We were not able to find in the scientific literature any experimental report linking this both issues. Tissue samples for carbonyl protein measurement were stored at $-80^{\circ} \mathrm{C}$ with liquid nitrogen and determination of the carbonyl content in tissue proteins followed a modified DNPH assay.,7 Our results showed that after an intestinal reperfusion insult the oxidative stress increases the levels of carbonyl protein. The ROC curve confirmed the high sensitivity and specificity of these measurements considering that the results are not far from the ideal curve, where the values reach the upper left corner of the graph. The present research was designed to evaluate the usefulness in determining carbonyl groups in protein extracts from the intestine. In the next step we intend to do another study in order to improve the applicability of that assay by using plasma samples, in the same experimental model.

\section{Conclusion}

Our data suggest that protein carbonyl level measurement is a useful and reproducible tool as a biomarker of the oxidative process after small bowel reperfusion.

\section{References}

1. Thompson A, Hemphill D, Jeejeebhoy KN. Oxidative stress and atioxidantes in intestinal disease. Dig Dis. 1998;16:152-8.

2. Schanaider A - Inativadores dos radicais livres derivados do oxigênio na isquemia intestinal. Tese - Livre Docência. UNI-RIO; 1990.

3. Levine RL, Williams JA, Stadman ER, Shacter E. Carbonyl assay for determination of oxidatively modified proteins. Methods Enzymol. 1994;233:346-57.
4. Choi J, Malakowsky CA, Talent JM, Conrad CC, Gracy RW. Identification of oxidized plasma proteins in Alzheimer's disease. Biochem Biophys Res Commmun. 2002;93:1566-70.

5. Buss H, Chan PT, Sluis KB, Domigan NM, Winterbourn CC. Protein carbonyl measurement by a sensitive Elisa method. Free Radic Biol Med. 1997;23:361-6.

6. Fagan JM, Sleczka BG, Sohar I. Quantitation of oxidative damage to tissue proteins. Int J Biochem Cell Biol. 1999;31:751-7.

7. Resnick AZ, Packer K. Oxidative damage to proteins: spectrophotometric method for carbonyl assay. Methods Enzymol. 1994;233:263-357.

8. Quinlan GJ, Evans TW; Gutteridge JM. Oxidative damage to plasma proteins in adult distress syndrome. Free Rad Res. 1994;20:289-98.

9. Smith MA, Perry G, Sayre IM, Anderson VE, Beal MF, Kowall N. Oxidative damage in Alzheimer's. Nature. 1996;382:120-1.

10. Stadman ER. Protein oxidation and aging. Science. 1992;257:1220-4.

11. Dalle Done I, Rossi R, Giustarini D, Gagliano N, Lusini L, Milzani A, Di Simplicio P, Colombo R. Actin carbonylation: from a simple marker of protein oxidation to relevant signs of severe functional impairment. Free Radic Biol Med. 2001;31:1075-83.

12. Powell SA, Gurzenda EM, Wahezi SE. Actin is oxidized during miocardial ischemia. Free Radic Biol Med. 2001;30:1171-6.

13. Pantke U, Volk T, Schmutzler M, Kox WJ, Sitte N, Grune T. Oxidized proteins as a marker of oxidative stress during coronary heart surgery. Free Radic Biol Med. 1999;27;1080-6.

14. Himmelfarb J, McMonagle E. Albumin is the major plasma protein target of oxidant stress in uremia. Kidney Int. 2001;60:358-63.

15. Lim PS, Cheng YM Wei YH. Increase in oxidative damage to lipids and proteins in skeletal muscle of uremic patients. Free Radic Res. 2002;36:295-301.

16. Fu S; Davies MJ, Stocker R, Dean RT. Evidence for roles of radicals in protein oxidation in advanced human atherosclerotic plaque. Biochem. 1998;333:519-25.

17. Banan A, Wang JY, McCormack SA, Johnson LR. Relationship between polyamines actin distribution and gastric mucosal ulcer haling in rats. Am J Physiol. 1996;271:G893-G903.

\section{Correspondence:}

Alberto Schanaider

Rua Eurico Cruz 33/603

22461-200 Rio de Janeiro - RJ Brazil

alberto-sch@ig.com.br
Conflict of interest: none Financial source: FAPERJ

Received: May 25, 2005

Review: June 21, 2005

Accepted: July 27, 2005

\section{How to cite this article:}

Schanaider A, Menezes VJMT, Borchardt AC, Oliveira PL, Madi K. Oxidized tissue proteins after intestinal reperfusion injury in rats. Acta Cir Bras. [serial on the Internet] 2005 Nov-Dec;20(6). Available from URL: http://www.scielo.br/acb

*Color figures available from www.scielo.br/acb 